\title{
Isolated Gallbladder Haematoma After Abdominal Blunt Trauma Without Surgery
}

\section{Künt Travmaya Bağlı İzole Safra Kesesi Hematomunda Konservatif Tedavi}

\author{
Cem DÖNMEZ ${ }^{1}$, Ezgi DÖNMEZ ${ }^{2}$, Canan GÜRSOY ${ }^{3}$, Funda DİNC ELIBBOL ${ }^{4}$, Sercan SUBAȘI ${ }^{1}$
}

\author{
${ }^{1}$ Mugla Sitki Kocman University, General Surgery Department, Muğla \\ ${ }^{2}$ Yatagan Public Hospital, Anesthesiology and Reanimation Clinic, Muğla \\ ${ }^{3}$ Mugla Sitki Kocman University, Anesthesiology and Reanimation Department, Muğla \\ ${ }^{4}$ Mugla Sitki Kocman University, Department of Radiology, Muğla
}

\begin{abstract}
Isolated gallbladder injury after trauma occurs rarely and when unrecognized mortality is too high. In some hemodynamically suitable cases, conservative treatment may be the best choise for the patient. We presented a case with conservatively treated abdominal trauma after stucking in the elevator and had isolated gallbladder injury.
\end{abstract}

Keywords: Abdominal Trauma, Blunt Trauma, Gallbladder Haematoma, Gallbladder Injury

\section{Öz}

Travma sonrası izole safra kesesi yaralanması nadir görülmekle birlikte tanı konulmadığında mortalitesi oldukça yüksektir. Hemodinamik olarak uygun vakalarda konservatif tedavi yaklaşımı hasta için en iyi seçenek olabilir. Bu yazımızda asansörde sıkışma sonucunda künt batın travmasına sekonder izole safra kesesi hematomu gelișen hastanın cerrahiye gerek kalmadan konservatif tedavi ile iyileşebileceğini vurguladık.

Anahtar Kelimeler: Batın Travması, Künt Travma, Safra Kesesi Hematomu, Safra Kesesi Yaralanmasi

physical examination, ecchymosis was noted across the upper abdomen and he had right upper abdomen tenderness. Murphy's sign was positive. Bowel sounds were not audible. Hemodynamic parameters were as follow: pulse 86 per minute, blood pressure $110 / 65 \mathrm{mmHg}$ and laboratory finding were as WBC: 2000, haematocrit: 31, Hb: $10 \mathrm{mg} / \mathrm{dl}$, platelet: 384000/mm3, GGT: $16 \mathrm{U} / \mathrm{L}$, ALT: $46 \mathrm{U} / 1$ (normal<40), AST: $104 \mathrm{U} / \mathrm{L}$ (normal<40), lactate dehydrogenase: $556 \mathrm{U} / \mathrm{L}$, amylase $270 \mathrm{U} / \mathrm{L}$, Bilirubin $0.25 \mathrm{mg} / \mathrm{dl}$.

The chest and abdomen $\mathrm{x}$-rays revealed no abnormalities (Figure 1). Abdomen CT showed an enlarged, hydropic gallbladder measuring $6 \times 4 \mathrm{~cm}$ and intraluminal hematoma (Figure 2). Ultrasonography (USG) showed heterogeneously hyperechoic lesions in the gallbladder but the surfaces were smooth. Abdomen CT and USG demonstrated a gallbladder wall without any signs of perforation or laceration (Figure 3). Also, there was no fluid collection and no injuries of the liver, spleen, kidneys or other abdominal structures. These imaging methods suggested isolated intragallbladder hemorrhage following blunt trauma.

The patient was referred to the intensive care and 4 hours later in the plain abdomen grapy, we ruled out the porcelain gallbladder. We decided to treat the patient conservatively. During the followup, temperatures were normal and vital signs were stable. The patient remained hemodynamically stable. In the physical examinations, the patient had diffuse epigastric tenderness without peritoneal signs. The patient didn't developed signs of jaundice. He was observed with the daily examination, with laboratory tests and USG, without laparotomy. The patient was discharged with full recovery. 


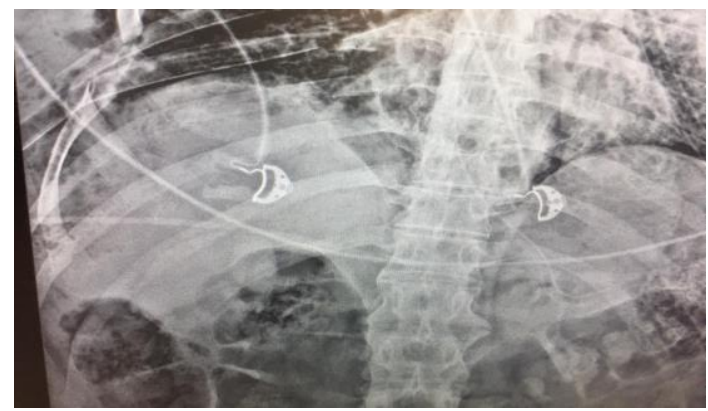

Figure 1. X-ray scan.

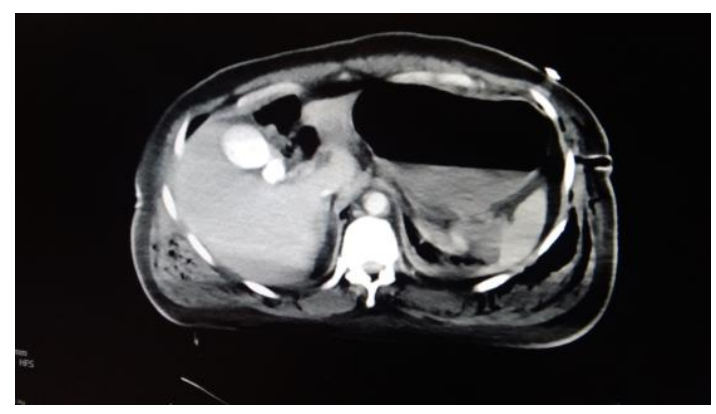

Figure 2. Abdomen CT scan.

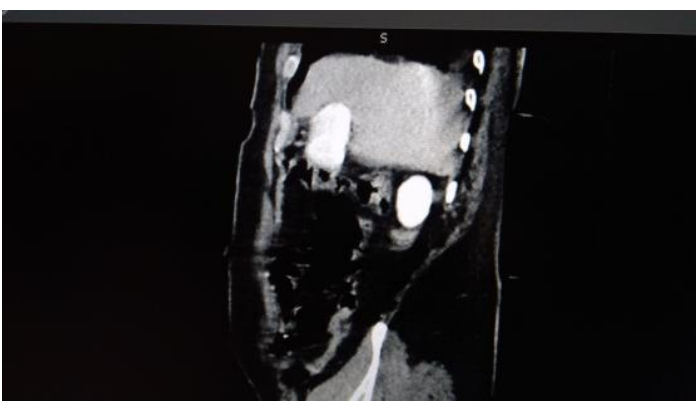

Figure 3. Abdomen CT scan.

\section{Discussion}

Isolated traumatic injury of the gallbladder after blunt trauma occurs rarely. In a study which involves 5670 cases of blunt and penetrating trauma reported the incidence of gallbladder trauma (not isolated) to be $1.9 \%$ (3)

The gallbladder is anatomically protected by the liver, omentum, and other intestinal organs, shielded by the rib cage. 4 The gallbladder damage is usually associated with the additional surrounding visceral injury.5 In a review of 22 patients of gallbladder injury, there was no isolated lesion.6 The liver lacerations are the most commonly seen injuries with gallbladder injuries. Along with the multiorgan injuries, gallbladder injuries have mortality about the \%24 rate, also $49 \%$ of them were severely injured with unstable hemodynamic status.7 The mortality and morbidity depend on complications of accompanying injuries (8).

The clinical signs and symptoms are not always helpful in diagnosis. There is a wide array of presented physical examinations from signs of an acute abdomen, hypovolaemic shock or mild tenderness. Usually, the patient's clinical symptoms develop slowly (9).

The blunt injury of the gallbladder occurs with several mechanisms, classified such as contusion, laceration, avulsion (10). Laceration defined as traumatic rupture or perforation of the gallbladder may present as bile leakage into the periton (11). The gallbladder contusion is commonly referred to intramural hematoma concluding discrete bruising of the gallbladder wall. The underlying mechanism of injury is contusion injury as a result of blunt trauma as in the current case. The avulsion injuries are the most severe injuries which are identified as partially torned gallbladder from its liver-bed or complete separation from the liver.

$\mathrm{CT}$ is the gold standard for the diagnose. In cases of abdominal traumas, recognition of high-density fluid within the gallbladder lumen is associated with fresh blood within the lümen $(12,13)$. Ultrasound and CT are the most reliable imaging techniques to confirm the diagnosis. CT scan is a better option to rule out adjacent organ injuries (14).

Cholecystectomy and percutaneous drainage are the choices of surgical treatment for gallbladder injury. Cholecystectomy is the safest surgical treatment for gallbladder injury. Minor contusions may be treated with close observation and supportive care. The gallbladder traumatic injury with larger rupture and major tearing requires cholecystectomy but conservative treatment is an option for selected patients (15). We followed isolated gallbladder traumatic injury with frequent examination, blood samples and ultrasound without surgery, and this is the pitfall on this case.

In conclusion, surgeons are mostly trained for the solution with surgery and we can make the decision for surgery more easily. In cases which exploratory laparotomy decision is challenging there may be a diagnosing interval for escaping from unnecessary laparotomy of gallbladder injuries. An example of an unusual form of gallbladder injury, conservative treatment results in full recovery in selected cases instead of surgery. There could be checkpoints to decide whether conservative treatment is appropriate instead of surgery when multiorgan injury is ruled out. The management of the gallbladder injury should be varied with the degree of injury. These factors could include such as vitals, hemodynamics, physical examination, CT, mechanism of injury, multiorgan injuries. Despite the limited cases of isolated gallbladder injuries in literature, there is a 
shift to nonsurgical management in hemodynamically stable minor contusion groups.

Written Consent: Written consent was taken from patient on 10.07.2019.

\section{References}

1. Salzman S, Lutfi R, Fishman D, Doherty J, Merlotti G Traumatic rupture of the gallbladder. J Trauma, 2006; 61(2):454-6.

2. Ball CG, Dixon E, Kirkpatrick AW, Sutherland FR, Laupland KB, Feliciano DV. A decade of experience with injuries to the gallbladder. J Trauma Manag Outcomes. 2010;4:3.

3. Penn I. Injuries of the gall-bladder. British J Surg. 1962; 49(218):636-41.

4. Epstein MG, Silva DL, Elias NC, Augusto Sica GT, Murillo de Fávaro L, Fontenelle Ribeiro MA. Isolated rupture of the gallbladder following blunt abdominal trauma: case report. Einstein (Sao Paulo). 2013;11: 227-8.

5. Nishiwaki M, Ashida H, Nishimura T, et al. Posttraumatic intra-gallbladder hemorrhage in a patient with liver cirrhosis. J Gastroenterol. 1999;34:282-5.

6. Sharma O. Blunt gallbladder injuries: presentation of twenty-two cases with review of the literature. J Trauma, 1995;39(3):576-80
7. Soderstrom CA. Maekawa K, DuPriest Jr RW, Cowley RA. Gallbladder injuries resulting from blunt abdominal trauma: an experience and review. Ann Surgery. 1981;193(1):60-6.

8. Tudyka V, Toebosch S, Zuidema W. Isolated Gallbladder Injury after Blunt Abdominal Trauma: a Case Report and Review. Eur J Trauma Emerg Surg. 2007;33(5):545-9.

9. Parks RW, Diamond T. Non-surgical trauma to the extrahepatic biliary tract. British J Surg. 1995;82(10):130310.

10. Wang IT, Tsai MT, Huang CY, et al. Isolated gallbladder hematoma after a blunt abdominal trauma: case report. Crit Ultrasound J. 2015;7:A27.

11. Johnson WR, Harris P. Isolated Gallbladder Injury Secondary To Blunt Abdominal Trauma: Case Report. Aust NZ J Surg. 1982;52(5):495-6.

12. Wittenberg A, Minotti AJ. CT Diagnosis of Traumatic Gallbladder Injury. Am J Roentgenol. 2005;185(6):1573-4.

13. Jeffrey RB Jr, Federle MP, Laing FC, Wing VW. Computed tomography of blunt trauma to the gallbladder. J Comput Assist Tomogr. 1986;10: 756-8.

14. Pavlidis TE, Lalountas MA, Psarras K, et al. Isolated complete avulsion of the gallbladder (near traumatic cholecystectomy): A case report and review of the literature. J Med Case Rep. 2011;5:392.

15. Birn J, Jung M, Dearing M. Isolated gallbladder injury in a case of blunt abdominal trauma. J Radiol Case Rep. 2012;6(4):25-30 